\title{
Effect of Pantothenic Acid on Hippurate Formation in Sodium Benzoate-Treated HepG $_{2}$ Cells
}

\author{
ANIL PALEKAR \\ Department of Pediatrics, Nassau County Medical Center, East Meadow, New York 11554, U.S.A.
}

\begin{tabular}{|c|c|}
\hline \multicolumn{2}{|c|}{ ABSTRACT } \\
\hline $\begin{array}{l}\text { Inborn errors of urea synthesis result in hyperammonemia. } \\
\text { Sodium benzoate (SB) therapy has been beneficial in the treat- } \\
\text { ment of hyperammonemia. It conjugates with glycine to form } \\
\text { hippurate, which is then excreted. SB has also been used to treat } \\
\text { children with nonketotic hyperglycinemia (NKH), where glycine } \\
\text { is removed, on conjugation, as hippurate. In mammalian liver } \\
\text { mitochondria, SB is activated by an ATP-dependent reaction to } \\
\text { its CoA ester, before conjugation with glycine. Pantothenic acid } \\
\text { (PA) is the precursor of CoA. In this investigation, increasing the } \\
\text { amounts of PA increased CoA levels in } \mathrm{HepG}_{2} \text { cells. It also }\end{array}$ & $\begin{array}{l}\text { significantly increased formation of hippurate in SB-treated cells. } \\
\text { These findings suggest a beneficial effect of PA on the SB } \\
\text { therapy in children with NKH as well as hyperammonemia. } \\
\text { (Pediatr Res 48: 357-359, 2000) } \\
\qquad \text { Abbreviations } \\
\text { SB, sodium benzoate } \\
\text { NKH, nonketotic hyperglycinemia } \\
\text { PA, pantothenic acid } \\
\text { CSF, cerebrospinal fluid }\end{array}$ \\
\hline
\end{tabular}

SB has been administered to patients suffering from hyperammonemia (1-4) due to genetic defects in the urea cycle (5, 6). Hyperammonemia also occurs in serious illnesses such as Reye's syndrome (7) and in some organic acidemias (8). SB conjugates with glycine to form hippurate, which is then excreted.

NKH is an inborn error of glycine metabolism characterized by intractable seizure, lethargy, severe psychomotor retardation, and early death $(9,10)$. Concentrations of glycine are elevated in plasma and CSF. Oral administration of SB lowered CSF and plasma glycine in these patients accompanied with attenuation of seizures (11-13).

The formation of hippurate from SB in mammalian liver mitochondria proceeds in two steps (14). First, in a reaction requiring ATP, benzyl CoA is formed by conjugation of $\mathrm{SB}$ and CoA. Benzyl CoA then reacts with glycine to form hippurate. Diversion of CoA for hippurate formation in isolated rat hepatocytes treated with $\mathrm{SB}$ caused depletion of CoA (15). In our studies in treatment of rats with $\mathrm{SB}$, we have shown a significant decrease in liver $\operatorname{CoA}(16,17)$. CoA is synthesized by cells from PA (18). In the absence of dietary PA, hepatic CoA content is significantly reduced (19). We have administered PA to a 4-mo-old patient with $\mathrm{NKH}$ who being treated with SB (20). Supplementation of PA resulted in attenuation of

Received March 29, 1999; accepted January 11, 2000.

Correspondence: Dr. Anil Palekar, Department of Pediatrics, Nassau County Medical Center, 2201 Hempstead Turnpike, East Meadow, NY 11554, U.S.A. seizures, increased urinary excretion of hippurate, and further decrease in glycine concentration in plasma and CSF. $\mathrm{HepG}_{2}$ cells, a human hepatoblastoma derived cell line, display morphology and function similar to that of liver parenchymal cells. $\mathrm{HepG}_{2}$ cells also retain drug-metabolizing capabilities and are used as an in vitro model of human hepatocytes (21).

In the present study, therefore, the effect of PA on formation of hippurate is investigated in SB-treated $\mathrm{HepG}_{2}$ cells.

\section{METHODS}

Materials. Tissue culture medium, FCS, glycine, calcium pantothenate, and other tissue culture supplies were obtained from Life Technologies, Inc. (Gaithersburg, MD, U.S.A.). SB, CoA, and hippurate were purchased from Sigma Chemical Co. (St. Louis, MO, U.S.A.). HepG $_{2}$ cells were obtained from American Type Culture Collection (Rockville, MD, U.S.A.).

Cell Culture. $\mathrm{HepG}_{2}$ cells were grown in $75-\mathrm{cm}^{2}$ flasks with $10 \mathrm{~mL}$ of Eagle's minimum essential medium supplemented with $10 \% \mathrm{FCS}, 100 \mathrm{IU}$ of penicillin $/ \mathrm{mL}, 0.1 \mathrm{mg}$ of streptomy$\mathrm{cin} / \mathrm{mL}$, and $2 \mathrm{mM}$ glutamine in a $37^{\circ} \mathrm{C}$ incubator with $5 \%$ $\mathrm{CO}_{2}$. Flasks were subcultured every $7 \mathrm{~d}$ with a split ratio of $1: 3$ using $0.25 \%$ trypsin in $\mathrm{Ca}^{2+}$ and $\mathrm{Mg}^{2+}$ free PBS for $10 \mathrm{~min}$ at $37^{\circ} \mathrm{C}$. For experiments, cells were seeded in $35-\mathrm{mm}$ dishes (six-well plates) at $10^{6}$ cells/well and were used after $24 \mathrm{~h}$. Medium was removed, cells were washed with PBS, and then $2 \mathrm{~mL}$ of medium, which was the same as described earlier but without any glycine, prepared from Hanks' balanced salt so- 
lution, essential amino acid mixture, nonessential amino acids, and vitamin mixture, and containing $10 \%$ dialyzed FCS was added. Viability of these cells was typically $>95 \%$ as determined by trypan blue exclusion. When PA content was $1 \mu \mathrm{g} / \mathrm{L}$ (essentially none) in the medium, viability of cells was $<90 \%$.

Additions of glycine, PA, and SB were carried out as recognized in different experimental conditions. After addition of PA and/or glycine, cells were incubated for $4 \mathrm{~h}$, washed with PBS, two to four wells pooled together by trypsin treatment, and then taken for CoA estimation as described by us (17) fluorometrically by the method of Williamson and Corkey (22).

In other experiments, SB was added to the medium and further incubation was carried out for $2 \mathrm{~h}$. The whole contents of the wells were used for estimation of hippurate. After adjusting to $\mathrm{pH} 4.0$ with hydrochloric acid, it was extracted with ethyl acetate and the organic phase was evaporated to dryness. Under these conditions, only hippurate is extracted in ethyl acetate, leaving glycine in aqueous phase. The residue was dissolved in $6 \mathrm{~N} \mathrm{HCl}$, hydrolyzed, and taken for estimation of glycine (formed from hippurate) on a Beckman amino acid analyzer.

\section{RESULTS}

Effect of addition of PA on CoA levels in $\mathrm{HepG}_{2}$ cells was studied as shown in Table 1. The concentration of PA was varied in the culture media from 1 to $5 \mathrm{mg} / \mathrm{L}$ at $1 \mathrm{mM}$ glycine. CoA concentration was not determined at PA concentration of $1 \mu \mathrm{g} / \mathrm{L}$, as under these conditions, viability of cells was $<90 \%$. At $1 \mathrm{mg} / \mathrm{L}$ of PA, CoA was $27.2 \pm 2.8$ pmoles $/ 10^{6} \mathrm{HepG} 2$ cells (mean $\pm \mathrm{SD}$ ), which increased significantly $(p<0.01)$ to $45.1 \pm 3.9$ at $2 \mathrm{mg} / \mathrm{L}$ and leveled off at $57.3 \pm 4.3$ to $59.6 \pm$ 3.8 pmoles $/ 10^{6} \mathrm{HepG}_{2}$ cells between 3 and $5 \mathrm{mg} / \mathrm{L}$. The results indicate that increasing PA from 1 to $3 \mathrm{mg} / \mathrm{L}$ caused an increase of $100 \%$ in CoA levels.

Effect of PA on formation of hippurate in $\mathrm{HepG}_{2}$ cells at varying glycine concentration of $0.5-5.0 \mathrm{mM}$ is shown in Figure 1. The concentration of PA studied was 1,2 , or $4 \mathrm{mg} / \mathrm{L}$ in the media whereas SB in all experiments was $0.5 \mathrm{mM}$. The experimental conditions, order of additions, and incubation times are described in "Methods." Under these conditions, at $0.5 \mathrm{mM} \mathrm{SB}$, less than $3 \%$ of it was converted to hippurate and the viability of the cells was $>95 \%$. Formation of hippurate

Table 1. Effect of PA on coenzyme A levels in Hep $G_{2}$ cells

\begin{tabular}{cc}
\hline $\begin{array}{c}\text { Pantothenic acid } \\
\mathrm{mg} / \mathrm{L}\end{array}$ & $\begin{array}{c}\text { Coenzyme A } \\
\text { pmoles } / 10^{6} \mathrm{HepG}_{2} \text { cells }\end{array}$ \\
\hline 1 & $27.2 \pm 2.8^{*}$ \\
2 & $45.1 \pm 3.9$ \\
3 & $57.3 \pm 4.3$ \\
4 & $59.8 \pm 4.0$ \\
5 & $59.6 \pm 3.8$ \\
\hline
\end{tabular}

Values are expressed as means \pm SD from six experiments. Cells were incubated in medium containing $1 \mathrm{mM}$ glycine for $4 \mathrm{~h}$ at $37^{\circ} \mathrm{C}$, after addition of PA. Cells were harvested and pooled together from two to four wells for the estimation of coenzyme A.

* Coenzyme A level at $1 \mathrm{mg} / \mathrm{L}$ PA was compared against other concentrations and was significantly lower $(P<0.01)$ by $t$ test.

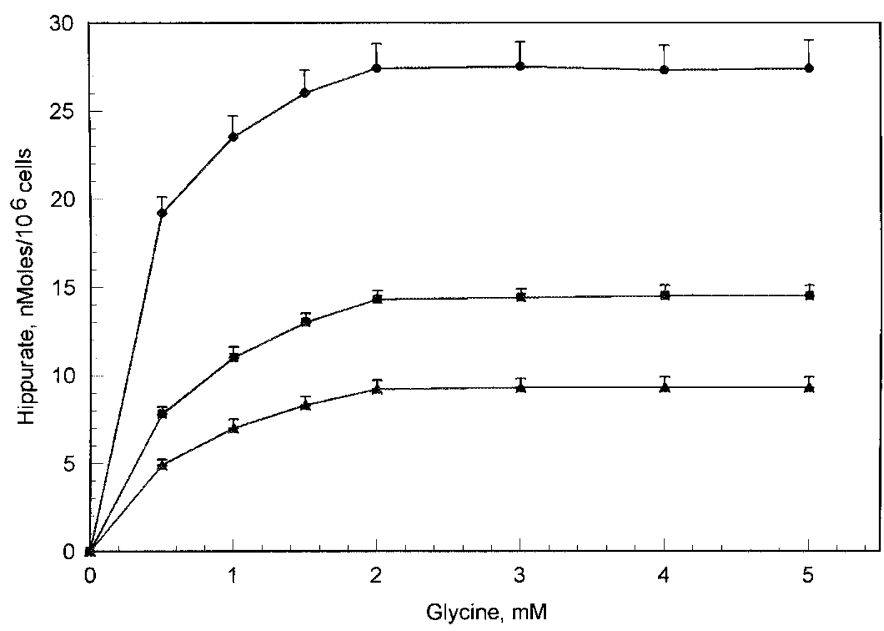

Figure 1. Effect of PA on hippurate formation in $\mathrm{HepG}_{2}$ cells. $\mathrm{HepG}_{2}$ cells containing PA at $1 \mathrm{mg} / \mathrm{L}$ ([trif]), $2 \mathrm{mg} / \mathrm{L}$ ([squlf]), or $4 \mathrm{mg} / \mathrm{L}$ ([circf]) in the medium were incubated with glycine $(0.5-5.0 \mathrm{mM})$ for $4 \mathrm{~h}$ at $37^{\circ} \mathrm{C}$. SB was added to give a concentration of $0.5 \mathrm{mM}$. After further incubation for $2 \mathrm{~h}$, hippurate formed in the wells was determined. Each point is an average of five determinations, and bars represent mean \pm SD.

increased as the amount of PA increased from 1 to 2 and 4 $\mathrm{mg} / \mathrm{L}$ when the glycine concentration was the same. At $1 \mathrm{mg} / \mathrm{L}$ of PA, hippurate formation per $10^{6} \mathrm{HepG}_{2}$ cells, was $4.9 \pm 0.3$ nmoles at $0.5 \mathrm{mM}$ glycine, increasing to $9.3 \pm 0.5$ nmoles at $2.0 \mathrm{mM}$ glucine. Further increase in glycine had no effect. At $2 \mathrm{mg} / \mathrm{L}$ of PA it was $7.8 \pm 0.6$ nmoles at $0.5 \mathrm{mM}$ glycine, leveling off to $14.3 \pm 0.7$ nmoles at $2.0 \mathrm{mM}$ glycine. Similarly, at $4 \mathrm{mg} / \mathrm{L}$ of PA, $19.2 \pm 1.0$ nmoles of hippurate was formed at $0.5 \mathrm{mM}$ glycine, increasing to $27.4 \pm 1.4$ at $2.0 \mathrm{mM}$ glycine. The increase in glycine concentration from 2.0 to $5.0 \mathrm{mM}$ had no further effect on hippurate formation at all the levels of PA studied. Similarly, increasing PA from 4 to $5 \mathrm{mg} / \mathrm{L}$ did not cause any further increase in hippurate formation.

\section{DISCUSSION}

Recent advances in the treatment of inborn errors of urea synthesis have significantly decreased mortality (23). Urea cycle disorders result in nitrogen accumulation, manifested by hyperammonemia. Treatment with SB results in conjugation with glycine to form hippurate and is excreted as waste nitrogen. Evidence of clinical toxicity from SB at recommended dosage of $1.73 \mathrm{mmol} / \mathrm{kg} / \mathrm{d}(250 \mathrm{mg} / \mathrm{kg} / \mathrm{d})$ has been rare. Green et al. (3) have shown that neonates form hippurate as effectively as older children (4). Beliveau and Brusilow (24) have suggested that glycine availability limits hippurate synthesis in vivo, leading to some toxic effects of SB. Studies with hepatocytes have shown (25) that glycine antagonizes the inhibition of ureagenesis by SB. Recently we have reported (16) that administration of SB to rats at a dose of $2.5 \mu \mathrm{mol} / \mathrm{kg}$ dropped plasma glycine levels from $310 \pm 30$ to $175 \pm 25 \mu \mathrm{mol} / \mathrm{L}$ at $2 \mathrm{~h}$, and at higher dosage, plasma glycine dropped to much lower levels and for more prolonged time.

$\mathrm{NKH}$ is an inborn error of glycine degradation in which large quantities of glycine accumulate in plasma and CSF (26). The primary biochemical defect is in the glycine cleavage system (EC 2.1.2.10), an intramitochondrial enzyme system 
present in the liver, kidney, and brain. High concentration of glycine in brain and CSF points to a defect mainly in the brain enzyme complex (27). No effective treatment has been reported consistently. SB has been used in the treatment because it reacts with glycine to form hippurate, which is then excreted $(12,13,20,26)$. Although benzoate doses as high as 3.5-5.2 $\mathrm{mmol} / \mathrm{kg} / \mathrm{d}(500-750 \mathrm{mg} / \mathrm{kg} / \mathrm{d})$ (26) have been used, they were not without toxicity $(20,28)$. When patients were treated with $\mathrm{SB}$ at $1 \mathrm{mmol} / \mathrm{kg}$ orally, serum concentration of SB reached $1.4-2.4 \mathrm{mM}(29)$, and in patients treated at $5.2 \mathrm{mmol} / \mathrm{kg} / \mathrm{d}$ it reached a concentration of $2.5-3.0 \mathrm{mM}$ in serum and sometimes as high as $9.8 \mathrm{mM}(28)$. We have used PA supplementation in the treatment of a patient with $\mathrm{NKH}$ in conjunction with SB. Because PA is a precursor of CoA, required for formation of hippurate, we were able to increase excretion of hippurate without increasing SB dose (20).

Other enzymes involved in the formation of hippurate may play a role in treatment with SB. Newborn children, due to a delayed development of hepatic and renal glycine-Nacyltransferase (EC 2.3.2.13), which conjugates benzyl CoA with glycine, may be more vulnerable to benzyl CoA toxicity (30).

The present study shows that increasing PA in the media caused an increase in the $\mathrm{CoA}$ levels in $\mathrm{HepG}_{2}$ cells. It also caused an increase in the formation of hippurate at $0.5-2.0 \mathrm{mM}$ glycine. PA supplementation may result in increased formation of hippurate in vivo by increasing CoA levels. This therapy may result in using lower doses of SB and thereby minimizing its toxic effects. Although increased hippurate formation might have been the result of CoA formation, other possibilities, such as direct transcriptional effect of PA on enzymes involved in hippurate synthesis, cannot be eliminated. Further experience will be required to determine the optimal relationships among dosages of PA and SB in the treatment of NKH and hyperammonemia.

\section{REFERENCES}

1. Batshaw ML, Brusilow SW 1980 Treatment of hyperammonemic coma caused by inborn errors of urea synthesis. J Pediatr 97:893-900

2. Batshaw ML, Brusilow SW, Waber LJ, Blom W, Bruback AM, Burton BK, Cann HM, Kerr D, Mamunes P, Matalon R, Myerberg D, Schaefer IA 1982 Treatment of inborn errors of urea synthesis. Activation of alternative pathways of waste nitrogen synthesis and excretion. N Engl J Med 306:1387-1392

3. Green TP, Marchessault RP, Freese DK 1983 Disposition of sodium benzoate in newborn infants with hyperammonemia. J Pediatr 102:785-790

4. Brusilow SW, Danney M, Waber LJ, Batshaw ML, Burton B, Levitsky L, Roth K, McKeethren C, Ward J 1984 Treatment of episodic hyperammonemia in children with inborn errors of urea synthesis. N Engl J Med 310:1630-1634
5. Brusilow SW, Horwich AL 1995 Urea cycle enzymes. In: Scriver CR, Beaudet AL, Sly WS, Valle D (eds) The Metabolic and Molecular Bases of Inherited Disease. McGraw-Hill, New York, pp 1187-1232

6. Colombo JP 1987 Urea cycle disorders, hyperammonemia and neurotransmitter changes. Enzyme 38:214-219

7. Reye RDK, Morgan G, Baraj J 1963 Encephalopathy and fatty degeneration of the viscera, a disease entity in childhood. Lancet 2:749-752

8. Sweetman L, Williams JC 1995 Branched chain organic acidurias. In: Scriver CR, Beaudet AL, Sly WS, Valle D (eds) The Metabolic and Molecular Bases of Inherited Disease. McGraw-Hill, New York, pp 1387-1422

9. Nyhan WL 1989 Nonketotic hyperglycinemia. In: Scriver CR, Beaudet AL, Sly WS, Valle D (eds) The Metabolic Basis of Inherited Disease. McGraw-Hill, New York, pp $743-753$

10. Gerritsen T, Kaveggia E, Waismen HA 1965 A new type of idiopathic hyperglycinemia with hypo-oxaluria. Pediatrics 36:882-891

11. Krieger I, Winbaum ES, Eisenbrey AB 1977 Cerebrospinal fluid glycine in nonketotic hyperglycinemia: effect of treatment with sodium benzoate and a ventricular shunt. Metabolism 26:517-524

12. Wolff JA, Kulovich S, Yu AL, Qiao CN, Nyhan WL 1986 The effectiveness of benzoate in the management of seizures in nonketotic hyperglycinemia. Am J Dis Child 140:596-602

13. Borshop BA, Breuer J, Holm J, Leslie J, Nyhan WL 1989 Excretion of hippuric acid during sodium benzoate therapy in patients with hyperglycinemia or hyperammonemia. J Inherited Metab Dis 12:72-79

14. Gatley JS, Sherratt HSA 1977 The synthesis of hippurate from benzoate and glycine by rat liver mitochondria. Biochem J 106:39-47

15. Ji M, Tremblay GC 1993 The relative toxicity of pivalate, benzoate, and valproate to gluconeogenesis, ureagenesis, and hippurate synthesis in isolated rat hepatocytes. Biochem Arch 9:33-40

16. Palekar AG, Kalbag SS 1991 Amino acids in the rat liver and plasma and some metabolites in the liver after sodium benzoate treatment. Biochem Med Metab Biol 46:52-58

17. Kalbag SS, Palekar AG 1988 Sodium benzoate inhibits fatty acid oxidation in rat liver: effect on ammonia levels. Biochem Med Metab Biol 40:133-142

18. Nakamura T, Kusunoki T, Soyama K 1967 Effect of pantothenic acid administration on 4-phosphopantetheine and dephospho-CoA content in rat liver determined by the use of biosynthesis reaction of $\mathrm{CoA}$ in vitro from these precursor substances. J Vitaminol 13:289-297

19. Smith CM, Narrow CM, Kendrick ZV, Steffon C 1987 The effect of pantothenate deficiency in mice on their metabolic response to fast and exercise. Metabolism 36:115-121

20. Angulo MA, Fuentes B, Palekar A, Castro-Magana M, Canas JA 1989 Pantothenic acid supplementation in an infant with nonketotic hyperglycinemia. J Ped Endocrinol $3: 185-188$

21. Lu SC, Huang H 1994 Comparison of sulfur amino acid utilization for GSH synthesis between $\mathrm{HepG}_{2}$ cells and cultured rat hepatocytes. Biochem Pharmacol 47:859-869

22. Williamson JR, Corkey BE 1969 Assays of intermediates of the citric acid cycle and related compound by fluorometric enzyme methods. Methods Enzymol 13:434-513

23. Batshaw ML, Monohan PS 1987 Treatment of urea cycle disorders. Enzyme 38:242 250

24. Beliveau GP, Brusilow SW 1987 Glycine availability limits maximum hippurate synthesis in growing rats. J Nutr 117:36-41

25. Cyr DM, Maswoswe SM, Tremblay GC 1987 Inhibition of the urea cycle and de novo pyridine biosynthesis by sodium benzoate. J Inherited Metab Dis 10:308-310

26. Hamosh A, Johnson MV, Valle D 1995 Nonketotic hyperglycinemia. In: Scriver CR, Beaudet AL, Sly WS, Valle D (eds) The Metabolic and Molecular Bases of Inherited Disease. McGraw-Hill, New York, pp 1337-1348

27. Tada K, Kure S 1993 Non-ketotic hyperglycinemia: molecular lesion, diagnosis and pathophysiology. J Inherited Metab Dis 16:691-703

28. Van Hove JLK, Kishani P, Muenzer J, Wenstrup RJ, Summar ML, Brummond MR, Lachiewicz AM, Millington DS, Kahler SG 1995 Benzoate therapy and carnitine deficiency in non-ketotic hyperglycinemia. Am J Med Genet 59:444-453

29. Oyanagi K, Kuniya Y, Tsuchiyama A, Nakao T, Owada E, Sato J, Ito K 1987 Nonlinear elimination of benzoate in patients with congenital hyperammonemia. J Pediatr 110:634-636

30. Mawal Y, Paradis K, Qureshi IA 1997 Developmental profile of mitochondrial glycine N-acyltransferase in human liver. J Pediatr 130:1003-1007 